\title{
Exposure of Toxocara canis eggs to Purpureocillium lilacinum as a biocontrol strategy: an experimental model evaluation
}

\author{
Exposição de ovos de Toxocara canis a Purpureocillium lilacinum como estratégia de biocontrole: \\ uma avaliação em modelo experimental \\ Fernando de Souza Maia Filho ${ }^{1,2}$; Anelise de Oliveira da Silva Fonseca²; Júlia de Souza Silveira Valente ${ }^{1,2}$; \\ Cristiane Telles Baptista ${ }^{1,2}$; Andrios da Silva Moreira ${ }^{1,2}$; Sônia de Avila Botton ${ }^{3}$; Luciana Pötter ${ }^{3}$; \\ Daniela Isabel Brayer Pereira ${ }^{1,2 *}$ (C) \\ ${ }^{1}$ Programa de Pós-graduação em Parasitologia, Departamento de Microbiologia e Parasitologia, Instituto de Biologia, Universidade \\ Federal de Pelotas - UFPel, Pelotas, RS, Brasil \\ ${ }^{2}$ Laboratório de Micologia, Departamento de Microbiologia e Parasitologia, Instituto de Biologia, Universidade Federal de Pelotas - \\ UFPel, Pelotas, RS, Brasil \\ ${ }^{3}$ Centro de Ciências Rurais, Universidade Federal de Santa Maria - UFSM, Santa Maria, RS, Brasil
}

Received September 17, 2018

Accepted December 12, 2018

\begin{abstract}
Purpureocillium lilacinum is a nematophagous fungus used in biological control against some parasites, including Toxocara canis. This study researched the infectivity of embryonated T. canis eggs after exposure to the fungus $P$. lilacinum. T. canis eggs were exposed to P. lilacinum for 15 or 30 days and subsequently administered to Swiss mice $(\mathrm{n}=20)$. Control group consisted of mice who received T. canis embryonated eggs without fungal exposure. Forty-eight hours after infection, heart, lung, and liver from animals of each group were collected to assess larval recovery. The organs of mice that received embryonated eggs exposed to the fungus showed a lower average larval recovery $(\mathrm{P}<0.05)$ suggesting that exposure of $T$. canis eggs to P. lilacinum was able to reduce experimental infection. Under the evaluated conditions, the interaction time between the fungus and the parasite eggs was not a significant factor in larvae recovery. P. lilacinum may be considered a promising T. canis biological control agent. However, further studies are needed to determine a protocol for the use of this fungus as a biological control agent.
\end{abstract}

Keywords: Geohelminths, ovicidal fungi, public health, environmental health, biological control.

\section{Resumo}

Purpureocillium lilacinum é um fungo nematófago com potencial para uso no controle biológico de parasitos, incluindo Toxocara canis. Este estudo pesquisou a infectividade de ovos de T. canis embrionados após exposição ao fungo P. lilacinum. Ovos de T. canis foram expostos ao fungo por 15 ou 30 dias e subsequentemente administrados a camundongos Swiss $(\mathrm{n}=20)$. O grupo controle consistiu de camundongos que receberam ovos embrionados do parasita sem exposiçáo ao fungo. Quarenta e oito horas após a infecção, coração, pulmáo e fígado dos camundongos foram coletados para avaliar a recuperaçáo larval. Os órgãos dos animais que receberam ovos embrionados expostos ao fungo apresentaram menor média de recuperação larval $(\mathrm{P}<0,05)$ do que os infectados com ovos sem exposição ao fungo, sugerindo que a exposição dos ovos de T. canis a P. lilacinum foi capaz de reduzir a infecção experimental. Nas condiçôes avaliadas, o tempo de interação entre o fungo e os ovos do parasito não foi um fator significativo na recuperação das larvas. P. lilacinum pode ser considerado um promissor agente de controle biológico de T. canis, no entanto, mais estudos são necessários para avaliar o emprego deste fungo como um agente de controle biológico.

Palavras-chave: Geohelmintos, fungos ovicidas, saúde pública, saúde ambiental, controle biológico. 


\section{Introduction}

Purpureocillium lilacinum, formerly known as Paecilomyces lilacinus, is a filamentous, soil saprobe fungus that is able to grow in wide $\mathrm{pH}$ ranges and uses different substrate sources (LUANGSA-ARD et al., 2011). This species of fungus has played a relevant role in the biological control of various parasites, such as Toxocara canis (BASUALDO et al., 2000; GORTARI et al., 2008; CARVALHO et al., 2010), Taenia hydatigena (CIARMELA et al., 2005), Taenia saginata, Moniezia sp. (BRAGA et al., 2008a,b), Dipylidium caninum (ARAUJO et al., 2009), Oxyuris equi (BRAGA et al., 2012), Fasciola hepatica (NAJAFI et al., 2017) and Ancylostoma (HOFSTÄTTER et al., 2017).

Nematophagous ovicidal fungi used in parasite biological control are able to colonize and digest nematode eggs in the soil. The egg infection begins with the growth of the fungal hyphae on the egg, which penetrate the egg wall via mechanical and/or enzymatic activity and rapidly colonize the entire egg (HUANG et al., 2004).

T. canis is an intestinal parasite of dogs, whose infection of paratenic hosts occurs mainly by accidental ingestion of embryonated eggs. Toxocariasis is a worldwide public health problem (CHEN et al., 2018; FAKHRI et al., 2018), because human exposure to this disease can be enhanced by environmental contamination, favored by the presence of dogs infected with T. canis, as well as the resistance of eggs in the soil. Places such as parks, squares, and beaches increase exposure of children to T. canis infection, especially those who are about five years of age, because of geophagia and nail biting habits (MACPHERSON, 2013). Humans behave as paratenic hosts of T. canis, preventing the full development of the helminth, but the larvae can survive for long periods in the body, migrating to different organs and tissues, where they remain encysted and viable resulting in diverse clinical manifestations, which are characterized as visceral larva migrans, ocular larva migrans, and covert toxocariasis syndromes (CHEN et al., 2018).

Given the problems caused by chemical control, especially its harmful effects on human health and the environment, the development of alternative methods of biological control is of paramount importance (MAIA et al., 2017). In this sense, biological control is a natural tool and an environmentally friendly alternative in the control of parasites of medical and veterinary relevance. This study investigated the experimental infectivity of embryonated $T$. canis eggs after exposure to the fungus P. lilacinum.

\section{Materials and Methods}

\section{Fungal isolate}

P. lilacinum used in this study was kindly provided by CENARGEN (National Research Center for Genetic Resources and Biotechnology, Brazil).

\section{T. canis embryonated eggs}

T. canis eggs were obtained by female parasite hysterectomy, as described by Maia et al. (2013). The eggs were put in a $2 \%$ formalin, $0.05 \%$ streptomycin sulfate, and $0.01 \%$ chloramphenicol solution. Embryonation was achieved by incubating the solution at $25^{\circ} \mathrm{C}$ for 30 days with daily aeration.

\section{P. lilacinum interaction with T. canis eggs}

Fungal culture discs were transferred into 10 Erlenmeyer flasks containing $150 \mathrm{ml}$ modified liquid minimal medium $\left[\mathrm{NH}_{4} \mathrm{NO}_{3}(0.4 \mathrm{~g} / \mathrm{L}) ; \mathrm{MgSO}_{4} 7 \mathrm{H} 2 \mathrm{O}(0.12 \mathrm{~g} / \mathrm{L}) ; \mathrm{Na}_{2} \mathrm{HPO}_{4} 7 \mathrm{H} 2 \mathrm{O}\right.$ $(3.18 \mathrm{~g} / \mathrm{L}) ; \mathrm{KH}_{2} \mathrm{PO}_{4}(0.26 \mathrm{~g} / \mathrm{L})$; yeast extract $\left.(0.3 \mathrm{~g} / \mathrm{L})\right]$. The flasks were incubated in a bacteriological incubator at $25^{\circ} \mathrm{C}$ with daily manual stirring for 15 days. On the 15 th day, 500 embryonating T. canis eggs were added to each flask containing the fungal culture and incubated under the same conditions described above for an additional 15 or 30 days. Additionally, 10 flasks containing parasite eggs (with no fungal contact) were maintained under the same culture conditions as the control group ( 15 or 30 days). At the end of the fungus and egg interaction periods, the culture medium was centrifuged at $2000 \mathrm{rpm}$ for 5 minutes. The supernatant was discarded and the pellet was resuspended in $1 \mathrm{ml} 0.01 \mathrm{M}$ phosphate buffer solution, pH 7.4 (PBS). To count the eggs and viability evaluation, $10 \mu \mathrm{L}$ of the solution was analyzed by light microscopy at a magnification of 400X. The eggs were considered viable when there was larva inside.

\section{Scanning Electron Microscopy (SEM)}

To perform SEM, P. lilacinum culture discs were transferred into four Erlenmeyer flasks containing $100 \mathrm{~mL}$ modified liquid minimal medium incubated in a bacteriological incubator at $25^{\circ} \mathrm{C}$ with daily manual stirring for 15 days. On the 15 th day, 500 embryonated T. canis eggs were added to flasks containing the fungal culture and incubated under the same conditions described above. Two flasks were incubated for 15 days and the other two flasks were incubated for 30 days. Two flasks containing parasite eggs (with no fungus contact) were maintained under the same culture conditions as the control group (15 and 30 days). By the end of the evaluation period (15 and 30 days) the samples were fixed in 3\% glutaraldehyde and $0.05 \mathrm{M}$ phosphate buffer $(1000 \mu \mathrm{L}$ glutaraldehyde: $300 \mu \mathrm{L}$ culture), at $\mathrm{pH} 6.8$, and maintained at $4^{\circ} \mathrm{C}$ for 48 hours. Subsequently, the cultures were fractionated into Falcon tubes and centrifuged for 15 minutes at $8000 \mathrm{rpm}$, discarding the supernatant. The precipitate was then subjected to successive ethanol baths $(30,50,70$, and 95\%) and kept in $100 \%$ ethanol for 15 minutes. After this period, the samples were transferred to Petri dishes and dried in a bacteriological oven at $37^{\circ} \mathrm{C}$ for 3 hours. After drying, the samples were fixed to the stubs with double carbon tape and covered with gold in the sputtering equipment (Denton Vacuum Desk V) for 120 seconds at $19 \mathrm{mM}$, being visualized at $15 \mathrm{KV}$, under magnification from 400 to 2,500X (Jeol, JSM - 6610LV, EUA).

\section{Experimental model}

Eight-week-old female Swiss mice (Mus musculus) were acquired from the animal facility at Universidade Federal de Pelotas (UFPel). The animals were kept in proper cages room at 
temperature of $25^{\circ} \mathrm{C}$, receiving food and water ad libitum. In the first experiment, control group $(n=20)$ animals were infected by oral route with with $0.2 \mathrm{~mL}$ PBS containing 100 embryonated T. canis eggs. The treatment group $(\mathrm{n}=20)$ consisted of mice that were infected with $0.2 \mathrm{~mL}$ PBS containing 100 embryonated T. canis eggs, which had been exposed to P. lilacinum for 15 days. The second experiment was carried out under the same conditions as the first, but the eggs that were given to the treatment group mice were exposed to the fungus for 30 days.

Forty-eight hours after infection, the mice from both experiments were euthanized through cervical dislocation as approved by the Ethics Committee on Animal Experimentation protocol of the UFPel (CEEA 0678). The liver, lung and heart of all animals were removed for larval recovery. The organs were macerated and digested in $50 \mathrm{ml} \mathrm{1 \%}$ hydrochloric acid and $1 \%$ pepsin solution by constant stirring at $120 \mathrm{rpm}$ at $37^{\circ} \mathrm{C}$ overnight. Subsequently, the digested organs were subjected to centrifugation at $2000 \mathrm{rpm} / 5$ minutes. The supernatant was discarded and the total precipitate of each organ was examined between a slide and cover slip under optical microscopy at magnifications of $100 \mathrm{X}$ and $400 \mathrm{X}$ for larval count (XI \& JIN, 1998).

\section{Statistical analysis}

The data for larval counting from the digested organs in both experiments were subjected to a normality test using Kolmogorov-Smirnov. As the response variable did not show normality, data were submitted to the non-parametric Kruskal-Wallis test. Thereafter, the Mood's median test was applied to compare means two to two. The analysis was performed using SAS statistical software (version 9.4), with a 5\% significance level.

\section{Results}

Microscopic analysis of embryonated eggs of the control group (T. canis eggs not exposed to the fungus) showed that the eggs were embryonated and intact (Figure 1A). However, the eggs that were incubated with the nematophagous fungus $P$. lilacinum were embryonated and colonized with fungal hyphae across their surface (Figure 1B). SEM observation revealed that the surfaces of the $T$. canis eggs in the control group were intact, and no destroyed eggs were observed (Figure 2A). However, in T. canis eggs exposed to P. lilacinum hyphae were observed colonizing the surface and the inside of the eggs, and subsequently destroying them. This effect was observed in eggs exposed to the fungus for 15 and 30 days (Figure 2B, 2C, and 2D).

Table 1 shows the average of $T$. canis larval recovery from heart, lung, and liver from mice experimentally infected with $T$. canis eggs exposed or not to P. lilacinum. The organs of the animals that received the embryonated eggs exposed to the fungus showed lower average recovery rate $(\mathrm{P}<0.05)$ than those from organs infected with embryonated $T$. canis eggs which were not exposed to the fungus (Table 1). Furthermore, there were no differences $(\mathrm{P}>0.05)$ between treatments when the periods of exposure of the eggs to the fungus were compared (Table 1).

\section{Discussion}

P. lilacinum, along with other nematophagous fungi, is a promising biocontrol agent because of its ability to capture and infect nematodes. In vitro studies evaluating the use of ovicidal fungi in T. canis biocontrol suggest that the use of these agents is an ecological and viable tool, complementary to other available
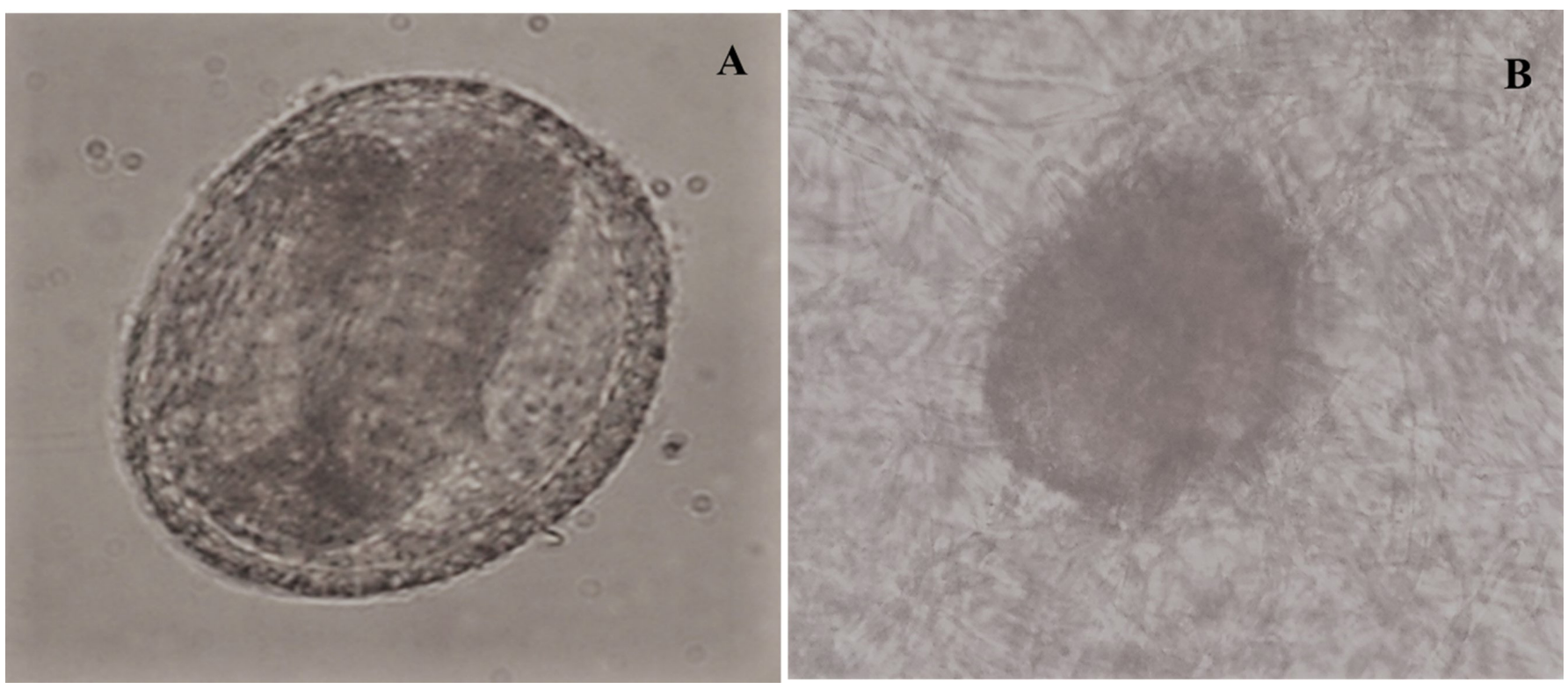

Figure 1. Light microscopy of T. canis eggs. (A) Control group: Embryonated T. canis egg not exposed to P. lilacinum. The eggs were incubated in minimal medium at $25^{\circ} \mathrm{C}$ for 15 and 30 days. No morphological alterations were observed (magnification 400X); (B) T. canis egg colonized by P. lilacinum hyphae after culturing in minimal medium at $25^{\circ} \mathrm{C}$ for 15 and 30 days. Note the colonized egg with fungal hyphae across its surface. This effect was observed over both periods of incubation time. 

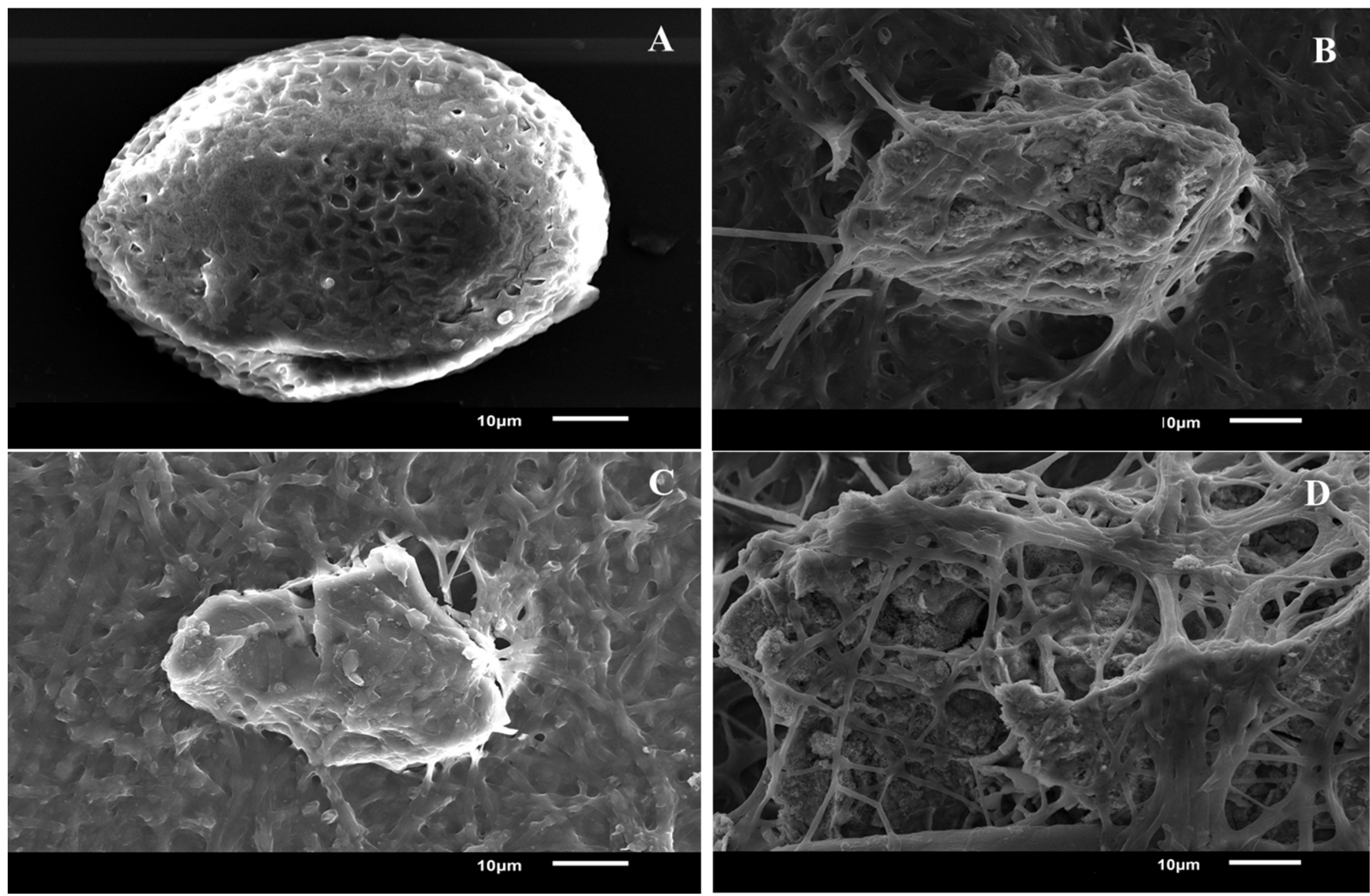

Figure 2. Scanning electron microscopy of T. canis eggs. (A) Control group: T. canis egg not exposed to P. lilacinum. T. canis eggs evaluated at 15 and 30 days, with surface intact and no destroyed eggs; (B) T. canis eggs exposed to P. lilacinum for 15 days and (C) 30 days. Hyphae colonizing the surface and interior of the egg are apparent for both periods of time; (D) T. canis eggs destroyed by P. lilacinum. Magnification 1400X.

Table 1. Mean count of Toxocara canis larvae in the organs of Mus musculus infected with T. canis eggs exposed to Purpureocillium lilacinum.

\begin{tabular}{lcccc}
\hline \multicolumn{4}{c}{ Mean count of T. canis larvae } \\
\hline \multirow{2}{*}{ Organ } & Control $^{*}$ Group $^{1 *}$ & \multicolumn{2}{c}{ Treatment (days) } \\
\cline { 3 - 5 } & $37.9^{\mathrm{a}}$ & $\mathbf{1 5}$ & $\mathbf{3 0}$ \\
\hline Liver & $14.6^{\mathrm{a}}$ & $9.7^{\mathrm{b}}$ & $19.2^{\mathrm{b}}$ & $9.5^{\mathrm{b}}$ \\
Lung & $14.1^{\mathrm{a}}$ & $9.5^{\mathrm{b}}$ & $4.5^{\mathrm{b}}$ \\
Heart & $66.6^{\mathrm{a}}$ & $39.1^{\mathrm{b}}$ & $33.2^{\mathrm{b}}$ \\
Experimental group mean & &
\end{tabular}

Different letters in the lines mean significant difference $(\mathrm{P}<0.05)$; ${ }^{1}$ Animals infected with embryonated T. canis eggs; ${ }^{2}$ Animals infected with embryonated T. canis eggs exposed to P. lilacinum for 15 or 30 days; ${ }^{*}$ The values correspond to the mean of the control group for 15 or 30 days.

control measures used against gastrointestinal parasites of relevance to public health (BASUALDO et al., 2000; ARAUJO et al., 2009; CARVALHO et al., 2010; MAIA et al., 2013).

Our study used mice as experimental model to show the recovery of larvae from the tissues of animals infected with T. canis eggs previously exposed to P. lilacinum and observed that it was lower $(\mathrm{P}<0.05)$ than the ones from the organs of mice infected with embryonated eggs that had not been exposed to the fungus. The results of this study may be explained by the likely reduction in egg viability resulting from structural injuries caused by the fungi, and the damage to larval development, as already seen by Lysek (1978). In the present study, SEM analysis provided evidence of hyphae colonizing the surface and interior of $T$. canis eggs exposed to $P$. lilacinum, with subsequent damage and destruction of the eggs' layers. Similar effects on T. canis eggs were described by Basualdo et al. (2000), Ciarmela et al. (2002) and Araujo et al. (2012a) testing other nematophagous fungi.

Interestingly, our study also observed that the interaction time between $P$. lilacinum and $T$. canis eggs did not influence the fungus action on the eggs. There were no significant differences (P> 0.05) between the recovery of larvae at 15 and 30 days of exposure to the fungus (Table 1). Araújo et al. (1995) reported that the ovicidal effect (type 3 effect) of the fungus could occur from the seventh day of interaction. Maia et al. (2013), while evaluating the ovicidal effect of different kinds of isolated soil fungi on T. canis eggs, observed that type 3 effect occurring from the 14th day of egg-fungal exposure.

The ovicidal effect of the fungus on parasite eggs occurs by mechanical and enzymatic action. Although the pathogenic 
mechanisms of nematophagous fungi are not yet fully understood, evidence shows that extracellular hydrolytic enzymes, including proteases, collagenases, and chitinases, may be involved in the penetration and digestion of nematode egg structures (HUANG et al., 2004; YANG et al., 2007). Nevertheless, several mechanisms of action have been suggested to explain the biological activity of $P$. lilacinum against nematodes. The main mechanism of action is by direct infection of the nematode eggs. P. lilacinus produces serine protease, which plays an important role in the penetration of the fungus in nematode eggs (BONANTS et al., 1995). In this research, we did not evaluate enzymatic effects of $P$. lilacinum on T. canis eggs. However, we did observe morphological alteration and destruction of $T$. canis eggs caused by exposure to P. lilacinum, as previously described by Basualdo et al. (2000).

In vivo studies reporting the use of nematophagous fungi are in their infancy. The literature includes few reports of predator nematophagous fungi of the genera Duddingtonia, Monacrosporium, and Arthrobotrys, where experimental passage of the fungus through the gastrointestinal tract of domestic animals is evaluated (ARAUJO et al., 2012b; TAVELA et al., 2013). Nevertheless, the in vivo exposition of helminth eggs with ovicidal nematophagous fungi and their subsequent effect on the infection process has been reported by Araujo et al. (2012a) and Maia et al. (2017).

This is the first report demonstrating the in vivo effectiveness of the nematophagous fungus $P$. lilacinum to reduce $T$. canis infection in experimental animals. Previously, our research group demonstrated that exposure of $T$. canis eggs to another nematophagous fungi (T. virens) for 15 days significantly reduced the number of larvae recovered from the organs of experimentally infected mice (MAIA et al., 2017).

The idea of using $P$. lilacinum as a biological control agent in contexts with high environmental $T$. canis egg contamination is promising. One of the benefits to public health would be a reduction in the risk of infection of susceptible individuals, especially children and the definitive host itself. Another advantage of this kind of biological control would be the contribution to environmental health as it could enable less use of chemicals, thus minimizing both the contamination of the environment with hazardous compounds and the selective pressure on parasites to evolve resistance to anti-parasitic drugs.

\section{Conclusion}

The exposure of T. canis eggs to P. lilacinum was able to reduce mice experimental infection. In addition, parasite-fungus interaction time beyond 15 days did not affect larval recovery. Thus, P. lilacinum may be considered a promising $T$. canis biological control agent. Nevertheless, further studies are necessary to evaluate the use of this fungus in the environment as a biological control agent.

\section{Acknowledgements}

The authors would like to thank the CNPq (Conselho Nacional de Desenvolvimento Científico e Tecnológico) and CAPES (Coordenação de Aperfeiçoamento de Pessoal de Nível Superior) of Brazil for student and researcher scholarships.

\section{References}

Araujo JM, Araújo JV, Braga FR, Araújo DM, Ferreira SR, Soares FE, et al. Survival of Pochonia chlamydosporia in the gastrointestinal tract of experimentally treated dogs. Res Vet Sci 2012a; 93(2): 803-806. http:// dx.doi.org/10.1016/j.rvsc.2011.10.019. PMid:22100247.

Araujo JM, Araújo JV, Braga FR, Tavela AO, Ferreira SR, Soares FEF, et al. Control of Strongyloides westeri by nematophagous fungi after passage through the gastrointestinal tract of donkeys. Rev Bras Parasitol Vet 2012b; 21(2): 157-160. http://dx.doi.org/10.1590/S1984-29612012000200016. PMid:22832758.

Araujo JM, Braga FR, Araújo JV, Carvalho RO. Atividade dos fungos nematófagos Pochonia chlamydosporia e Paecilomyces lilacinus sobre cápsulas de ovos de Dipylidium caninum. Rev Inst Adolfo Lutz 2009; 68(3): 488-491.

Araújo JV, Santos MA, Ferraz S. Efeito ovicida de fungos nematófagos sobre ovos embrionados de Toxocara canis. Arq Bras Med Vet Zootec 1995; 47(1): 37-42.

Basualdo JA, Ciarmela ML, Sarmiento PL, Minvielle MC. Biological activity of Paecilomyces genus against Toxocara canis eggs. Parasitol Res 2000; 86(10): 854-859. http://dx.doi.org/10.1007/PL00008513. PMid:11068820.

Bonants PJM, Fitters PFL, Thijs H, den Beider E, Waalwijk C, Henfling JWDM. A basic serine protease from Paecilomyces lilacinus with biological activity against Meloidogyne hapla eggs. Microbiology 1995; 141(Pt 4): 775784. http://dx.doi.org/10.1099/13500872-141-4-775. PMid:7773385.

Braga FR, Araújo JV, Araujo JM, Carvalho RO, Silva AR, Campos AK, et al. Ovicidal activity of Paecilomyces lilacinus on Moniezia sp. eggs. J Helminthol 2008a; 82(3): 241-243. http://dx.doi.org/10.1017/ S0022149X08977488. PMid:18613986.

Braga FR, Araújo JV, Araujo JM, Carvalho RO, Silva AR. Efeito do fungo Paecilomyces lilacinus sobre ovos de Taenia saginata. Rev Soc Bras Med Trop 2008b; 41(6): 686-688. http://dx.doi.org/10.1590/S003786822008000600026. PMid:19142455.

Braga FR, Araújo JV, Soares FEF, Tavela AO, Araujo JM, Carvalho $\mathrm{RO}$, et al. Enzymatic analysis and in vitro ovicidal effect of Pochonia chlamydosporia and Paecilomyces lilacinus on Oxyuris equi eggs of horses. Biocontrol Sci Technol 2012; 22(6): 685-696. http://dx.doi.org/10.1080 /09583157.2012.677807.

Carvalho RO, Araújo JV, Braga FR, Araujo JM, Alves CD. Ovicidal activity of Pochonia chlamydosporia and Paecilomyces lilacinus on Toxocara canis eggs. Vet Parasitol 2010; 169(1-2): 123-127. http://dx.doi.org/10.1016/j. vetpar.2009.12.037. PMid:20097478.

Chen J, Liu Q, Liu GH, Zheng WB, Hong SJ, Sugiyama H, et al. Toxocariasis: a silent threat with a progressive public health impact. Infect Dis Poverty 2018; 7(1): 59. http://dx.doi.org/10.1186/s40249018-0437-0. PMid:29895324.

Ciarmela ML, Minvielle MC, Lori G, Basualdo JA. Biological interaction between soil fungi and Toxocara canis eggs. Vet Parasitol 2002; 103(3): 251257. http://dx.doi.org/10.1016/S0304-4017(01)00598-2. PMid:11750118.

Ciarmela ML, Thevenet PS, Alvarez HM, Minvielle MC, Basualdo JA. Effect of Paecilomyces lilacinus on the viability of oncospheres of Taenia hydatigena. Vet Parasitol 2005; 131(1-2): 61-64. http://dx.doi. org/10.1016/j.vetpar.2005.04.031. PMid:15950384.

Fakhri Y, Gasser RB, Rostami A, Fan CK, Ghasemi SM, Javanian $\mathrm{M}$, et al. Toxocara eggs in public places worldwide - A systematic review 
and meta-analysis. Environ Pollut 2018; 242(Pt B): 1467-1475. https:// doi.org/10.1016/j.envpol.2018.07.087.

Gortari MC, Galarza BC, Cazau MC, Hours R. Comparison of the biological properties of two strains of Paecilomyces lilacinus (Thom) Samson associated to their antagonistic effect onto Toxocara canis eggs. Malays J Microbiol 2008; 4(2): 35-41. http://dx.doi.org/10.21161/mjm.12508.

Hofstätter BDM, Fonseca AOS, Maia FS Fo, Silveira JS, Persici BM, Pötter L, et al. Effect of Paecilomyces lilacinus, Trichoderma harzianum and Trichoderma virens fungal extracts on the hatchability of Ancylostoma eggs. Rev Iberoam Micol2017; 34(1): 28-31. http://dx.doi.org/10.1016/j. riam.2016.04.004. PMid:27810261.

Huang X, Zhao N, Zhang K. Extracellular enzymes serving as virulence factors in nematophagous fungi involved in infection of the host. Res Microbiol 2004; 155(10): 811-816. http://dx.doi.org/10.1016/j. resmic.2004.07.003. PMid:15567274.

Luangsa-Ard J, Houbraken J, van Doorn T, Hong SB, Borman AM, Hywel-Jones NL, et al. Purpureocillium, a new genus for the medically important Paecilomyces lilacinus. FEMS Microbiol Lett 2011; 321(2): 141-149. http://dx.doi.org/10.1111/j.1574-6968.2011.02322.x. PMid:21631575.

Lysek H. A scanning electron microscope study of the effect of an ovicidal fungus on the eggs of Ascaris lumbricoides. Parasitology 1978; 77(2): 139141. http://dx.doi.org/10.1017/S0031182000049337.

Macpherson CNL. The epidemiology and public health importance of toxocariasis: a zoonosis of global importance. Int J Parasitol 2013;
43(12-13): 999-1008. http://dx.doi.org/10.1016/j.ijpara.2013.07.004. PMid:23954435.

Maia FS Fo, Fonseca AOS, Persici BM, Silveira JS, Braga CQ, Pötter L, et al. Trichoderma virens as a biocontrol of Toxocara canis: In vivo evaluation. Rev Iberoam Micol 2017; 34(1): 32-35. http://dx.doi.org/10.1016/j. riam.2016.06.004. PMid:28109772.

Maia FS Fo, Vieira JN, Berne MEA, Stoll FE, Nascente PS, Pötter L, et al. Fungal Ovicidal Activity on Toxocara canis eggs. Rev Iberoam Micol 2013; 30(4): 226-230. http://dx.doi.org/10.1016/j.riam.2012.12.009. PMid:23402830.

Najafi F, Rezaie S, Kia EB, Mahmoudi M, Khodavaisy S, Mohebali $\mathrm{M}$, et al. In Vitro Assay of Paecilomyces lilacinus biocontrol effects on Fasciola hepatica eggs illustrated in scanning electron micrographs. Iran J Parasitol 2017; 12(1): 22-28. PMid:28761457.

Tavela AO, Araújo JV, Braga FR, Silveira WF, Silva VHD, Carretta M $\mathrm{Jr}$, et al. Coadministration of sodium alginate pellets containing the fungi Duddingtonia flagrans and Monacrosporium thaumasium on cyathostomin infective larvae after passing through the gastrointestinal tract of horses. Res Vet Sci 2013; 94(3): 568-572. http://dx.doi.org/10.1016/j. rvsc.2012.11.011. PMid:23274060.

Xi WG, Jin LZ. A novel method for the recovery of Toxocara canis in mice. J Helminthol 1998; 72(2): 183-184. http://dx.doi.org/10.1017/ S0022149X00016382. PMid:9687601.

Yang J, Tian B, Liang L, Zhang KQ. Extracellular enzymes and the pathogenesis of nematophagous fungi. Appl Microbiol Biotechnol 2007; 75(1): 21-31. http://dx.doi.org/10.1007/s00253-007-0881-4. PMid:17318531. 